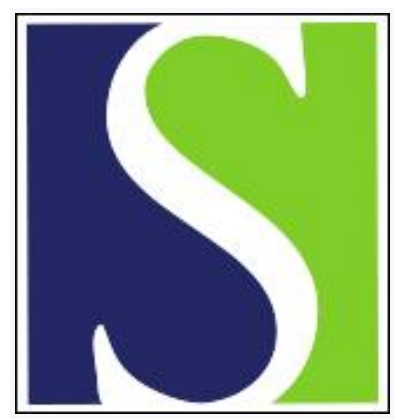

Scand J Work Environ Health 1999;25(5):387-403

https://doi.org/10.5271/sjweh.451

Issue date: Oct 1999

Physical load during work and leisure time as risk factors for back pain

by Hoogendoorn WE, van Poppel MNM, Bongers PM, Koes BW, Bouter LM

The following articles refer to this text: $2002 ; 28(5): 289-292$;

2002;28(5):293-303; 2002;28(5):304-313; 2002;28(5):314-323;

$2003 ; 29(5): 363-377 ; 2003 ; 29(6): 431-440 ; 2004 ; 30(4): 261-278$;

2004;30(5):390-398; 2004;30(6):459-467; 2007;33(1):1-3;

2010;36(1):34-41; 2012;38(6):582-589; 2013;39(6):589-598;

2016;42(6):528-537

Key terms: bending; lifting; low-back pain; methodological quality; observational study; rating system; review; sports; twisting; whole-body vibration

This article in PubMed: www.ncbi.nlm.nih.gov/pubmed/10569458

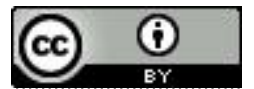




\title{
Physical load during work and leisure time as risk factors for back pain
}

\author{
by Wilhelmina E Hoogendoorn, MSc, ${ }^{1,2}$ Mireille NM van Poppel, MSc, ${ }^{1}$ Paulien M Bongers, PhD, ${ }^{2}$ Bart W \\ Koes, PhD, ${ }^{1}$ Lex M Bouter, PhD ${ }^{1}$
}

\begin{abstract}
Hoogendoorn WE, van Poppel MNM, Bongers PM, Koes BW, Bouter LM. Physical load during work and leisure time as risk factors for back pain. Scand J Work Environ Health 1999;25(5):387—403.

This systematic review assessed aspects of physical load during work and leisure time as risk factors for back pain. Several reviews on this topic are available, but this one is based on a strict systematic approach to identify and summarize the evidence, comparable with that applied in the clinical literature on the efficacy of intervention for back pain. A computerized bibliographical search was made of several data bases for studies with a cohort or casereferent design. Cross-sectional studies were excluded. A rating system was used to assess the strength of the evidence, based on the methodological quality of 28 cohort and 3 case-referent studies and the consistency of the findings. Strong evidence exists for manual materials handling, bending and twisting, and whole-body vibration as risk factors for back pain. The evidence was moderate for patient handling and heavy physical work, and no evidence was found for standing or walking, sitting, sports, and total leisure-time physical activity.
\end{abstract}

Key terms bending, lifting, low-back pain, methodological quality, observational studies, overview, rating system, sports, twisting, whole-body vibration.

Back pain is a major health problem in the Western world. The lifetime prevalence has been estimated at $60 \%$ to $90 \%$, and the point prevalence varies between $15 \%$ and $42 \%$, depending on the study population and the definition of back pain. The annual incidence of back pain has been reported to be approximately $5 \%(1-4)$.

In a recent study of a general population in The Netherlands, the annual prevalence of low-back pain was found to be $46 \%$ for men and $52 \%$ for women. This study also showed that the high prevalence of back pain has important consequences in terms of disability, the utilization of health services, and sick leave. Twenty-eight percent of the people with low-back pain were restricted in their daily activities, $42 \%$ underwent medical treatment, $23 \%$ took time off work, $8 \%$ received a (partial) disability pension, and $6 \%$ changed jobs or had adaptations in the workplace (5). In 1991, the total cost of back pain to society in The Netherlands was estimated to be $1.7 \%$ of the gross national product (6).

The prevalence rate of low-back pain also varies between workers in different professions. High prevalence rates are found, in particular, for nonsedentary occupations $(7,8)$. This phenomenon indicates that work-related factors may play a role in the etiology of back pain. In order to define potentially effective intervention in the workplace, the relationship between various exposures and back pain must be examined more specifically.

Several reviews on risk factors for back pain have already been published $(9-15)$. However, none of them include clearly defined inclusion and exclusion criteria, a methodological quality assessment of the studies, and explicit criteria on which overall conclusions on the strength of the evidence were based. The current interest in evidence-based medicine has led to an extensive increase in the publication of systematic reviews, because a systematic approach is less susceptible to bias. This increase has, in turn, led to the development of methodological guidelines for systematic reviews (16).

This paper examines the evidence for certain aspects of physical load as risk factors for back pain. Physical load is assumed to have both an acute and a cumulative effect on the occurrence of back pain. A load that exceeds the failure tolerance of the tissue, applied once, can cause back pain. However, cumulative load resulting from subfailure magnitude loads may be even more important. In such cases, back pain is assumed to be the result of a repeated application of loads or the long-term application of a sustained load. Moreover, a combination of cumulative and acute loads can also cause back pain $(17,18)$.

1 Institute for Research in Extramural Medicine, Vrije Universiteit, Amsterdam, The Netherlands.

2 TNO Work and Employment, Hoofddorp, The Netherlands.

Reprint requests to: TNO Work and Employment, Lisette Hoogendoorn, PO Box 718, 2130 AS Hoofddorp, The Netherlands. [E-mail: L.Hoogendoorn@arbeid.tno.nl] 
In this paper, a systematic approach, comparable with that applied in the clinical literature on the efficacy of intervention for back pain $(16,19)$, was used to answer the following research questions, based on the available literature: (i) which aspects of physical load at work are risk factors for the occurrence of back pain and (ii) which aspects of physical load during leisure time are risk factors for the occurrence of back pain?

\section{Material and methods}

\section{Search strategy and screening}

The available literature was identified by means of a computerized search of several bibliographical data bases, including Medline (1966-November 1997), Embase (1988-October 1997), Psyclit (1974-September 1997), NIOSHTIC, CISDOC and HSELINE (1977-July 1997), and Sportdiscus (1949-October 1997). The following key words were used: back pain, low-back pain, lumbago, backache, intervertebral disk displacement, hernia, herniated disc, sciatica, sciatic pain, risk factors, causality, causative, precipitating factors, determinants, predictor, etiology, aetiology, epidemiology, and case-control studies, retrospective studies, case-referent, prospective studies, longitudinal studies, follow-up studies, and cohort studies. For practical reasons, the search was restricted to publications in English, Dutch, German and French. The abstracts of all the citations were retrieved and examined.

\section{Selection}

A selection was made from the identified papers. The first reviewer (WH) was responsible for the entire selection, but in order to check the reproducibility of the selection process, a second reviewer (MP) selected a random sample $(\mathrm{N}=100)$ from the papers identified in Medline.

The studies had to meet the following inclusion criteria:

- The design of the study had to be case-referent or cohort (prospective or historical) with at least 1 year of follow-up. Studies with a cross-sectional design, defined as studies in which the exposure(s) and the disease were assessed at the same time, were excluded.

- The study had to concern a working population or a community-based population. Studies involving patient populations were excluded.

- The operationalization of back pain had to be based on symptoms or signs of nonspecific back pain, selfreported or measured otherwise, including such consequences of back pain as sick leave, medical consultation, or treatment and disability. Studies on back pain due to a definite herniated lumbar intervertebral disc diagnosed according to well-defined diagnostic criteria and studies on back pain due to osteoporosis, cancer, or other specific causes were excluded. Studies which focused on back pain during pregnancy were also excluded.

- The exposures accepted for study included physical load during work or physical load during leisure time. Studies which only involved a comparison between different occupational groups were excluded.

- The publication had to be a full report. Letters and abstracts were excluded.

The references of all the selected articles and recently published review articles $(9,11)$ were screened for additional, potentially eligible publications.

\section{Methodological quality assessment}

The selected studies were scored by two reviewers (WH, $\mathrm{MP}$ ), independently, on the basis of a standardized set of criteria. The criteria concerned the study population, the exposure measurements, the assessment of back pain, and the analysis and presentation of the data. Two slightly different, separate criteria lists were used for the cohort studies and the case-referent studies. A description of these 2 lists is given in the appendix. These lists were adapted from criteria lists used in systematic reviews of randomized controlled trials on treatment (16) and criteria lists used in other reviews of observational studies $(20$, 21).

The reviewers rated each criterion according to the following rules: $+=$ informative description of the criterion at issue, and study meets the criterion, - = informative description, but study does not meet the criterion, and ? = lacking or insufficient information, assigning " + " or "-" was not possible.

All disagreements between the reviewers were subsequently discussed during a consensus meeting. If disagreements were not resolved during this meeting, a third reviewer (PB) was consulted for a final judgment. Each study was assigned a total methods score, which was the sum of all positive ratings for the criteria on validity and precision. This evaluation finally resulted in a hierarchical order for both the cohort and the case-referent studies, ranking the studies according to their methodological quality.

\section{Data extraction and analysis}

Data on the effect of the exposures of interest were abstracted from the text and tables of the original publications. Whenever possible, the data extraction not only included information on the statistical significance of the effect, but also on the magnitude of the estimated effect. For some studies that did not provide an effect estimate, this figure was computed from the data provided in the article. If a study (only) reported that a factor did not 
enter the model in stepwise modeling, this result was disregarded in the data extraction because a stepwise analysis is not appropriate for modeling focused on the assessment of a causal relationship (22).

Due to the expected heterogeneity with regard to the study population, exposure measurements, and assessment of back pain, it had been previously decided to refrain from statistically pooling the findings of the individual studies. In order to synthesize the available information, use was made of a method based on levels of evidence adapted from the US Clinical Practice Guideline for Acute Low Back Pain in Adults (23). The rating system was applied to each individual exposure, and it consisted of 3 levels of scientific evidence based on the number, the quality, and the outcome of the studies as follows: (i) strong evidence: provided by generally consistent findings in multiple high-quality studies, (ii) moderate evidence: provided by generally consistent findings in 1 high-quality study and ${ }^{3} 1$ low-quality studies, or in multiple low-quality studies, (iii) no evidence: only 1 study available or inconsistent findings in multiple studies. Strong or moderate evidence could concern both the presence and the absence of an effect. A study was considered to be of high quality if the methodological quality score was more than $50 \%$ of the maximum score, and low-quality studies were those with a methodological score of less than $50 \%$ of the maximum score. The findings of the studies were considered to be inconsistent if less than $75 \%$ of the available studies reported the same conclusion. In the case of multiple high-quality studies, the available low-quality studies were disregarded in the drawing of an overall conclusion.

In the assessment of the level of evidence for an exposure, an increased risk was regarded as a positive effect, regardless of the statistical significance. A risk estimate [relative risk (RR) or odds ratio (OR)] in the region of 1 was considered to indicate no effect, and a decreased risk was considered to indicate a negative effect, notwithstanding the statistical significance of this effect. Studies that only reported nonsignificance, without presenting an effect estimate, were excluded from the evaluation. This exclusion, and ignoring the statistical significance of the findings, was based on the fact that, in general, the information provided in the articles was too meager to evaluate if no significant effect was found, either because there was no effect or because of a lack of statistical power, due to a small study size, a small percentage of exposed subjects, or a small percentage of subjects who developed the disease in question (24). As ignoring the statistical significance could be controversial, the exposures for which it was concluded that there was strong or moderate evidence of an effect were subjected to a sensitivity analysis. In this analysis all the studies with a nonsignificant effect were considered to indicate no effect.
If studies reported results of analyses with different outcome measures, the assessment of the effect was based on the results obtained for symptoms and findings, as opposed to measures of the consequences of back pain such as sick leave, medical consultation or treatment and disability. If studies reported results of analyses in different subgroups, the studies were considered to indicate a positive or a negative effect if such an effect was found in at least 1 of the subgroups.

\section{Resulis}

\section{Selection}

The literature search in the various data bases resulted in the identification of 1363 publications, mostly in English. Twenty-seven studies met the inclusion criteria (25-93). On the basis of a screening of the references of the articles on these studies and recent reviews $(9,11)$, an additional 9 studies were included (94-104). The selection of studies for inclusion, from a random sample $(\mathrm{N}=100)$ of the papers identified in Medline by the second reviewer, led to an initial $2 \%$ disagreement. Five of the 36 selected studies were excluded post hoc for the following reasons: (i) there was low variability in physical load because the study population was restricted to workers with lifting tasks $(50,51,95,98,99)$, (ii) the physical exposures at work were measured by means of a questionnaire on which only 1 of a list of items could be ticked (85), and (iii) the early retirements that were studied did not necessarily have a back disorder as the main diagnosis $(25,26)$. Thus a total of 31 studies was finally included in this review, comprised of 28 cohort studies $(27-49,52-76,78,82-84,86-94,96,97$, $100,102-104)$ and 3 case-referent studies $(77,79-81$, 101). For most of the studies there was more than 1 publication, and the assessment of the methodological quality of these studies was based on the information provided in all the publications.

\section{Methodological quality assessment}

The scoring of the 28 cohort studies and the 3 case-referent studies led to an overall initial disagreement of $20 \%$ (95 of 476 items) and 25\% (14 of 57 items), respectively. The 2 reviewers subsequently reached consensus on all the initial disagreements.

Tables 1 and 2 show the cohort and case-referent studies on physical load as a risk factor for back pain in order of their methodological quality score. Eleven of the $28(39 \%)$ cohort studies $(28-45,49,52,61-71,73,78$, $82-84,86,100)$ and 2 of the $3(67 \%)$ case-referent studies $(77,79-81)$ had a positive score for over $50 \%$ of the criteria on validity and precision, and they were therefore considered to be of high quality. 
Table 1. Cohort studies on physical load during work and leisure time as risk factors for back pain, ranked according to their methodological quality scorea

\begin{tabular}{|c|c|c|c|c|c|c|c|c|c|c|c|c|c|c|c|c|c|c|}
\hline Authors & 1 & 2 & 3 & 4 & 7 & 8 & 9 & 10 & 11 & 12 & 13 & 17 & 18 & 19 & 21 & 22 & 23 & $\begin{aligned} & \text { Percentage } \\
+ & \text { V/P }(=3-23)\end{aligned}$ \\
\hline $\begin{array}{l}\text { Biering-Sørensen } \\
\text { et al }(28-36)\end{array}$ & + & + & + & + & + & $?$ & + & $?$ & + & - & + & + & + & $=$ & + & + & + & 73 \\
\hline Leino et al $(61-66)$ & + & - & + & + & + & $?$ & + & $?$ & + & . & + & + & + & - & + & + & + & 73 \\
\hline Bigos et al $(37-45)$ & + & + & * & $?$ & + & $?$ & + & $?$ & + & + & + & $?$ & + & + & + & + & + & 67 \\
\hline Burdorf et al (49) & + & + & + & + & + & $?$ & - & - & + & - & + & $?$ & + & - & + & + & + & 60 \\
\hline Rilhimäki et al $(82-84)$ & + & + & - & + & + & $?$ & + & $?$ & + & - & + & $?$ & + & - & + & + & + & 60 \\
\hline Klaber-Moffet et al (52) & + & + & + & + & - & - & - & - & + & - & + & $?$ & + & + & - & + & + & 53 \\
\hline Macfarlane et al $(67-71)$ & + & + & - & - & + & $?$ & + & $?$ & - & + & - & + & + & + & + & + & + & 53 \\
\hline Mannion et al (73) & + & + & $?$ & + & + & $?$ & - & - & + & - & + & $?$ & + & - & + & + & + & 53 \\
\hline Pietri et al (78) & + & + & $?$ & + & + & $?$ & - & - & + & . & + & $?$ & + & - & + & + & + & 53 \\
\hline Ready et al $(100)$ & + & + & - & + & - & - & + & $?$ & + & - & + & $?$ & + & + & + & + & - & 53 \\
\hline Rossignol et al (86) & + & + & - & + & - & - & + & $?$ & + & - & + & $?$ & + & + & + & + & - & 53 \\
\hline Smedley et al $(91,92)$ & + & + & - & - & + & $?$ & - & - & - & - & + & $?$ & + & + & + & + & + & 47 \\
\hline Videman et al (103) & + & + & $?$ & + & + & $?$ & - & - & + & - & - & $?$ & + & - & + & + & + & 47 \\
\hline Biering-Sørensen et al (27) & + & + & + & + & + & $?$ & - & - & - & - & - & $?$ & + & - & - & + & + & 40 \\
\hline Gyntelberg et al $(96,97)$ & + & + & + & + & + & ? & - & - & + & - & - & $?$ & + & - & + & - & - & 40 \\
\hline Kuh et al $(53,54)$ & + & + & + & + & - & - & - & - & - & - & - & $?$ & + & - & + & + & + & 40 \\
\hline Kujala et al $(55-59)$ & + & + & + & + & - & - & - & - & + & - & - & $?$ & + & - & + & + & - & 40 \\
\hline Kujala et al $(60)$ & + & + & - & - & + & $?$ & - & - & + & - & + & $?$ & + & - & - & + & + & 40 \\
\hline Manninen et al (72) & + & + & + & - & + & $?$ & - & - & - & - & + & $?$ & + & - & + & + & - & 40 \\
\hline Venning et al (93) & + & - & - & + & + & $?$ & - & - & - & - & - & $?$ & + & + & - & + & + & 40 \\
\hline Muramatsu et al (75) & + & + & - & + & - & - & - & - & + & - & + & $?$ & - & - & - & + & + & 33 \\
\hline Niedhammer et al (76) & + & + & $?$ & + & - & - & - & - & + & - & + & $?$ & + & - & - & + & $?$ & 33 \\
\hline Vilkari-Juntura et al (104) & + & + & $?$ & - & $?$ & $?$ & + & $?$ & + & $?$ & - & $?$ & + & - & + & + & - & 33 \\
\hline Stobbe et al (102) & + & - & $?$ & $?$ & - & - & - & - & - & - & - & $?$ & + & + & + & + & + & 33 \\
\hline Bergenudd \& Nilsson (94) & + & + & $?$ & - & - & - & + & $?$ & $?$ & - & - & $?$ & - & - & + & + & + & 27 \\
\hline Salminen et al $(87-90)$ & + & + & + & + & - & - & - & - & + & - & - & $?$ & + & - & - & - & - & 27 \\
\hline Mooney et al (74) & + & - & + & $?$ & - & - & - & - & - & - & - & $?$ & + & + & + & - & - & 27 \\
\hline Brattberg et al $(46-48)$ & + & + & + & + & - & - & - & - & + & - & - & $?$ & - & - & - & - & - & 20 \\
\hline
\end{tabular}

a The numbers refer to the numbers of the criteria in the list for the methodological quality assessment in the appendix: $+=y e s,=n 0, ?=d o n ' t$ know.

Table 2. Case-referent studies on physical load during work and leisure time as risk factors for back pain, ranked according to their methodological quality scorea.

\begin{tabular}{|c|c|c|c|c|c|c|c|c|c|c|c|c|c|c|c|c|c|c|c|c|}
\hline Authors & 1 & 2 & 5 & 6 & 7 & 8 & 9 & 10 & 11 & 12 & 13 & 14 & 15 & 16 & 17 & 20 & 21 & 22 & 23 & $\begin{array}{c}\text { Percentage } \\
+ \text { V/P }(=5-23)\end{array}$ \\
\hline $\begin{array}{l}\text { Punnett et al } \\
(79-81)\end{array}$ & + & + & + & + & + & + & - & - & + & - & + & - & + & - & $?$ & + & + & + & + & 65 \\
\hline $\begin{array}{l}\text { Nuwayhid } \\
\text { et al (77) }\end{array}$ & + & - & - & - & + & $?$ & + & $?$ & + & + & + & + & - & - & + & + & + & + & + & 65 \\
\hline $\begin{array}{l}\text { Ryden } \\
\text { et al (101) }\end{array}$ & + & + & - & $?$ & - & - & + & $?$ & + & - & + & + & $?$ & + & $?$ & - & + & + & - & 41 \\
\hline
\end{tabular}

a The numbers refer to the numbers of the criteria in the list for the methodological quality assessment in the appendix; $+=y e s,-=n o, ?=d o n ' t$ know.

Tables 3 and 4 give a detailed description of important aspects of the cohort and case-referent studies included in the review.

\section{Physical load at work}

\section{Lifting: manual materials handling and patient handling}

Four high-quality studies and 1 low-quality study reporting on the effect of manual materials handling were identified $(53,67,77-79)$. Manual materials handling includes lifting, moving, carrying, and holding loads. Three high-quality studies found a statistically significant positive effect for manual materials handling (67, $77,79)$ and 1 high-quality study found no effect $(78)$. According to these findings there is strong evidence for manual materials handling as a risk factor for back pain. The magnitude of the risk estimates [relative risk (RR) or odds ratio (OR)] ranged from 1.5 to 3.1 .

Three low-quality studies examined the effect of patient handling $(91,93,102)$. Patient handling includes the 
Table 3. Summary of the cohort studies on physical load and back pain. (MQS = methodological quality score based on items on validity and precision, $N S=$ not significant, $R R=$ relative risk, $O R=$ odds ratio, the corresponding $95 \%$ confidence intervals for the $R R$ and $O R$ are shown in parentheses)

\begin{tabular}{|c|c|c|c|}
\hline Authors & MQS & Study population & $\begin{array}{l}\text { Operationalization } \\
\text { of back pain }\end{array}$ \\
\hline $\begin{array}{l}\text { Bergenudd \& } \\
\text { Nilsson }(94)^{\mathrm{a}}\end{array}$ & 4 & $\begin{array}{l}154210 \text {-year-old residents } \\
\text { of Malmö, } 830 \text { included in } \\
1983 \text {, follow-up response } \\
69 \%\end{array}$ & $\begin{array}{l}\text { Present back pain at follow- } \\
\text { up in } 1983 \text { (questionnaire) }\end{array}$ \\
\hline $\begin{array}{l}\text { Biering-Sørensen } \\
\text { et al ( } 27)\end{array}$ & n 6 & $\begin{array}{l}72850 \text {-year-old inhabitants } \\
\text { of Copenhagen, follow-up } \\
\text { response } 85 \%\end{array}$ & $\begin{array}{l}\text { 1. Low-back pain during } \\
\text { last } 10 \text { years } \\
\text { 2. Absences from work due } \\
\text { to low-back pain during last } \\
10 \text { years (interview) }\end{array}$ \\
\hline $\begin{array}{l}\text { Biering-Sørensen } \\
\text { et al }(28-36)^{b}\end{array}$ & n 11 & $\begin{array}{l}92830-, 40-, 50-\text { and } 60-y e a r \\
\text { old inhabitants of Copenhagen, } \\
\text { follow-up response } 99 \% \\
\text { Analysis restricted to } 351 \\
\text { persons with no low-back } \\
\text { trouble before base line }\end{array}$ & $\begin{array}{l}\text { Low-back pain within the } \\
\text { last } 12 \text { months } \\
\text { (questionnaire) }\end{array}$ \\
\hline $\begin{array}{l}\text { Bigos et al } \\
(37-45)^{b}\end{array}$ & 10 & $\begin{array}{l}3020 \text { blue-collar workers at } \\
\text { one of the plants of Boeing- } \\
\text { Everett }\end{array}$ & $\begin{array}{l}\text { Incident reports or claims } \\
\text { for acute back injury } \\
\text { complaints }\end{array}$ \\
\hline $\begin{array}{l}\text { Brattberg et al } \\
(46-48)^{c}\end{array}$ & 3 & $\begin{array}{l}1245 \text { children (8-, } 11-, 13- \\
\text { and } 17 \text {-year-olds), } 597 \text { includ- } \\
\text { ed in the longitudinal study, } \\
\text { follow-up response } 79 \%\end{array}$ & $\begin{array}{l}\text { Often having back pain at } \\
\text { follow-up (questionnaire) }\end{array}$ \\
\hline Burdorf et ald (49) & 9) 9 & $\begin{array}{l}221 \text { male novice golfers } \\
20 \text {-to-60-year-olds, follow-up } \\
\text { response } 89 \%\end{array}$ & $\begin{array}{l}\text { Back pain during past } 12 \\
\text { months (questionnaire) }\end{array}$ \\
\hline $\begin{array}{l}\text { Gyntelberg et al } \\
(96,97)\end{array}$ & 6 & $\begin{array}{l}5249 \text { men aged } 40-59 \text { years } \\
\text { and employed in large private } \\
\text { or public enterprises, follow- } \\
\text { up response } 91 \%\end{array}$ & $\begin{array}{l}\text { Low-back pain during the } \\
\text { past year (questionnaire } \\
\text { or interview) }\end{array}$ \\
\hline
\end{tabular}

1 year, 2 measurements persons sweat [RR $R_{\text {noy and then-rarely ar never } 1.24}$

12 months, $2 \quad$ Work (questionnaire): physical activity at work measurements (NS) Nonwork (questionnaire): physical activity
during leisure time (NS)

1 day-4 years (mean 3 years)

Work (questionnaire): perceived physical exertion (NS at $\mathrm{P}=0.00132$ )

2 years, 2

Nonwork (questionnaire): frequency of measurements participation in physical activities (NS)

12 months, 2 Work (questionnaire, subjects without history measurements of back pain): standing or walking $>4$ hours/ day (NS), sitting $>4$ hours/day (NS) Nonwork (questionnaire, subjects without history of back pain): various aspects of playing golf (NS), involvement in other sports $[R R=0.36(0.07-1.83)]$

Work (questionnaire): work on the job makes

$(1.12-1.38), R R_{\text {often-rarely or never }} 1.45(1.23-$ $1.72)]$, physical activity on the job (heavy and sedentary compared with light) ( $P \leq 0.05)$

Nonwork (questionnaire): bicycling/day $\left[R_{11-}\right.$ $20 \mathrm{~min}-510 \min 0.95(0.82-1.09), R_{21-30 \mathrm{~min}-}$ $\leq 10 \mathrm{~min} 1.05(0.89-1.25), \mathrm{RR}_{>30 \mathrm{~min}-\leq 10 \mathrm{~min}}$ $0.91(0.78-1.06)$, often sweating from leisure-time physical activity [RR $1.03(0.92-$ 1.14)], taking regular part in sports $[R R=0.84$ $(0.74-0.96)]$

Klaber Moffett $\quad 8 \quad 376$ female student nurses $\quad 1 . \geq 3$ days of low-back et al $(52)^{d}$ recruited on entry to 2 schools of nursing, follow-up response $80 \%$ 2. $\geq 21$ days low-back pain or 1 day of sick leave with back pain during follow-up (diaries collected at approximately 3 monthly intervals)

Kuh et al $(53,54)^{\mathrm{e}} 6 \quad 5362$ single, legitimate births that occurred in England, Wales, or Scotland in 1 week in March 1946, response at Recalled first ever experienced sciatica, lumbago or severe backache at age 43 relevant follow-up $61 \%$ Analysis restricted to 1566 men with job histories and no back pain before 16 years of age $(55-59)$

6116 athletes and nonathletes; soccer players) and girl

3 years, 4

Nonwork (questionnaire outcome 1): exercise

20 months, 7

habits at base line (number of times a

sporting activity was given up) $(P \leq 0.05)$

43 years, 20 measurements

Work (job-exposure matrix): regular lifting of weights in excess of $25 \mathrm{~kg}\left[R R_{\text {high-low probability }} 1.3\right.$ $(1.0-1.7)]$

Nonwork (questionnaire, outcome 1): weekly frequency or duration of training before base line (NS), training years before base line (NS), frequency or duration of training during the years preceding low-back-pain report (NS) Nonwork (adjusted for gender, outcome 1): participation in sports [ $\mathrm{RR}_{\text {athletes-nonathletes }} 2.45$ $(1.13-5.31)]$

Nonwork (outcome 2): participation in sports $\left[R_{\text {athletes-nonathletes }} 1.90(0.70-5.28)\right]$ 
Table 3. Continued.

\begin{tabular}{|c|c|c|c|c|}
\hline Authors & MQS & Study population & $\begin{array}{l}\text { Operationalization } \\
\text { of back pain }\end{array}$ & Follow-up \\
\hline Kujala et al (60) & 6 & $\begin{array}{l}45625-, 35-, 45-\text { and } 55-y e a r- \\
\text { olds from Turku, Finland, } \\
\text { without acute or chronic } \\
\text { disease, severe or recent back } \\
\text { symptoms or other musculo- } \\
\text { skeletal symptoms, follow-up } \\
\text { response } 57 \%\end{array}$ & $\begin{array}{l}\text { 1. Back pain during the past } \\
5 \text { years } \\
\text { 2. Back pain radiating to the } \\
\text { leg during the past } 5 \text { years } \\
\text { (questionnaire) }\end{array}$ & $\begin{array}{l}5 \text { years, } 2 \\
\text { measurements }\end{array}$ \\
\hline $\begin{array}{l}\text { Leino et al } \\
(61-66)^{d}\end{array}$ & 11 & $\begin{array}{l}902 \text { blue- and white-collar } \\
\text { employees of metal industry } \\
\text { plants, follow-up } \\
\text { response } 67 \%\end{array}$ & $\begin{array}{l}\text { 1. Low-back symptom score } \\
\text { during the past } 12 \text { months } \\
\text { at the last follow-up } \\
\text { (questionnaire) } \\
\text { 2. Low-back clinical findings } \\
\text { score (physiotherapist) }\end{array}$ & $\begin{array}{l}10 \text { years, } 3 \\
\text { measurements }\end{array}$ \\
\hline
\end{tabular}

Results

Work (questionnaire, outcome 1): general

occupational physical demands ( $P \leq 0.05$ )

occupational musculoskeletal loading

(job-exposure matrix) $(\mathrm{P} \leq 0.05)$

Nonwork (questionnaire, outcome 1): leisure

physical activity (NS)

Work (questionnaire, outcome 2): general

occupational physical demands ( $P \leq 0.05)$,

occupational musculoskeletal loading (job-

exposure matrix) ( $P \leq 0.05)$

Nonwork (questionnaire, outcome 2): leisure

physical activity (NS)

Work (questionnaire, outcome 1 and 2):

physical load (NS)

Nonwork (questionnaire base line, outcome 1 and 2): total activity outside work in kilocalories (NS)

Nonwork (mean questionnaire base line and first follow-up, adjusted for low-back symptoms at 1 st follow-up, age, occupational class, smoking intensity, body mass index and stress symptoms, outcome 1): exercise activity in kilocalories for men (st.beta -0.078) $(P \leq 0.05)$ and women (st.beta $-0.001 ; N S)$

Work (questionnaire, adjusted for age of cohort members with no history of low-back pain, outcome 1 and 2 combined): Standing or walking $>2$ hours [OR $1.6(0.8-3.3)]$, sitting $>2$ hours [OR $0.9(0.1-1.5)]$, driving a car $>4$ hours [OR $1.1(0.5-2.7)]$, lifting/moving $\geq 25 \mathrm{lb}$ [OR $1.5(0.8-2.8)]$ for men and stand ing/walking $>2$ hours $[O R 2.9(1.5-5.5)$ ], sitting $>2$ hours [OR $0.4(0.2-0.7)$ ], driving a car $>4$ hours [OR $4.8(0.4-54)$ ], lifting/moving $\geq 25$ pounds OR $2.0(1.0-4.0)]$ for women Work (questionnaire, adjusted for gender,

Manninen

et al (72)

Mannion

et al (73)

6537 Finnish farmers aged

1. Sciatic pain during the $45-54$ years who reported no past year low-back or neck-shoulder pain 2.Unspecified low-back pain during the past year at base during the past year line, follow-up response $68 \%$ (telephone interview)

8403 volunteering health-care 1. Back-related pain during workers aged $18-40$ years follow-up who had no history of serious 2. Back-related pain with low-back or leg pain, follow-up medical consultation or response $92 \%$ treatment or time absent from work during follow-up (questionnaire every 6 months during follow-up)

Mooney et al (74) $4 \quad 3643$ employees of a large shipbuilding firm including workers in 32 job categories claims

Muramatsu et al (75)

5 2200 noninstitutionalized ol follow-up response $90 \%$ Analysis focused on those currently not suffering from low-back pain at base line

Self-reported "chronic low- 3 years, 2 back pain" (interview at measurements follow-up)

18 months, 4 measurements outcome 1): use of a tractor [RR $0.78(0.32$ 1.89)]

Work (questionnaire, adjusted for gender, outcome 2): use of a tractor [RR $1.42(0.53-$ 3.76)]

Work (questionnaire, outcome 1 and 2): heaviness of job (NS)

Nonwork (questionnaire, outcome 1 and 2): frequency of leisure exercise (NS)

Work (job-exposure matrix): physical demand level, based on lifting requirements and energy required [ $R R_{\text {Iight-sedentary }} 0.73(0.25-$ 2.18), $\operatorname{RR}_{\text {mediurt-sederitary }} 4.52(2.70-7.56)$, $\mathrm{RR}_{\text {heary-sedentary }} 13.28(8.02-22.00)$, $\left.\mathrm{RR}_{\text {very heavy-sadentary }} 9.79(5.73-16.73)\right]$ Nonwork (interview, adjusted for age, gender, education, marital status, contact with child psychological distress, have friend or neighbor, social contact, social participation, instrumental support, emotional support, smoking, drinking, comorbidity, self-rated health and functional limitations): physical activity (frequency of yard work, exercise or sports and walking, NS)

10 years, $3 \quad$ Nonwork (questionnaire 1985, adjusted for measurements at age, children $\leq 3$, tobacco, symptoms of 5 -year intervals psychological disorders, commuting, and psychosocial and physical factors at work): sports activities (OR=1.11, NS) 
Table 3. Continued.

\begin{tabular}{lllll}
\hline Authors & MQS Study population & $\begin{array}{l}\text { Operationalization } \\
\text { of back pain }\end{array}$ & Follow-up \\
\hline Pietri et al (78) & 8 & $\begin{array}{l}1381 \text { commercial travelers, } \\
\text { follow-up response } 81 \% \\
\text { Analysis restricted to } 627 \\
\text { people who had never had low- } \\
\text { back pain before the base line }\end{array}$ & $\begin{array}{l}\text { Symptoms of low-back pain } 12 \text { months, } 2 \\
\text { during the past } 12 \text { months }\end{array}$ & measurements \\
& &
\end{tabular}

Ready

et al $(100)$

Riihimäki et al $(82-84)^{\text {d, g }}$
$8 \quad 131$ full-time female nurses and unit assistants, follow-up response $91 \%$

92222 male longshoremen and earthmover operators, carpenters and municipal off workers aged $25-49$ years follow-up response $82 \%$

Analysis restricted to 1149 men who had never had sciatic pain at base line

Rossigno et al (86)

\section{2} workers, follow-up response $76 \%$

\section{Salminen} et al $(87-90)$

476 eighth grade students follow-up response $82 \%$

Smedley et al $(91,92)^{d}$
Back injuries reported by the 18 months employees on an employee accident report

3 years, 2 incidence of sciatic pain measurements (questionnaire)

Work (questionnaire, adjusted for draft and cold, high pace of work, monotonous work, problems with workmates or superiors and the other variables shown ): amount of twisted or bent postures ( $\mathrm{P} \leq 0.05)$, vibration $(\mathrm{P} \leq 0.05)$

Nonwork (questionnaire, adjusted for smoking and the other variables shown): annual car driving (NS), weekly physical exercise $(\mathrm{P} \leq 0.05)$ Nonwork (questionnaire, adjusted for occupa tion, smoking and history of other low-back

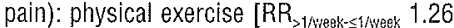
$(1.00-1.60)]$

Nonwork (questionnaire, outcome 1, 2, 3, 4): number of hours spent in sport or physical activities in past week (NS)

12 months, 2 problem during follow-up measurements (computerized records) 2. Absenteeism for a back problem during follow-up (computerized records) 3. Limitation in work performance in preceding week (questionnaire) 4. Back symptoms in preceding week (questionnaire)

Low-back pain during the 3 years, 3 past 12 months at last measurements follow-up (questionnaire and interview)

1. Low-back pain $>1$ day 2 years, 8

during follow-up measurements 2. Low-back pain leading to loss of time from work during follow-up (three monthly questionnaires during the whole follow-up)
7961 hospital-based nurses without low-back pain in the month before they completed the base-line questionnaire, response after 12 months $66 \%$ earlier history of low-back pain, and

symptoms other than back pain at base line, outcome 1): frequency in average work shift: transfer patient on canvas and poles $\left[0 R_{104-0}\right.$ $\left.0.8(0.6-1.1), 0 \mathrm{R}_{\geq 5-0} 1.4(0.8-2.3)\right]$ manually transfer patient between bed and chair $\left[0 R_{1 \text { to } 4-0} 1.3(0.9-1.7), 0 R_{5 \text { to } 9-0} 1.6\right.$ $\left.(1.1-2.3), O R_{>10-0} 1.6(1.1-2.3)\right]$, transfer patient between bed and chair with hoist $\left[0 R_{1 \text { to } 4-1} 1.5(1.0-2.0), O R_{25-0} 1.6(0.8-\right.$ 2.3)], manually move patient around on bed $\left[O R_{104-0} 1.3(0.8-1.9), O R_{5109-0} 1.5(1.0\right.$ 2.3), $\left.O R_{z 10-0}-1.7(1.1-2.5)\right]$, manually lift patient up off floor $\left[O R_{z 1-0} 1.1(0.9-1.5)\right]$ lift patient from floor with hoist $\left[0 \mathrm{R}_{>1-0} 1.3\right.$ $(0.8-2.0)]$, manually lift patient in or out of bath $\left[O R_{21-0} 0.9(0.6-1.4)\right]$, lift patient in or out of bath with hoist $\left[0 \mathrm{R}_{1 \text { to } 4-0} 1.4(1.0-\right.$

1.9), $\left.O R_{\approx-0} 2.1(1.2-3.6)\right]$ Work (job-exposure matrix, adjusted for

Stobbe et al (102) 5415 licensed practical nurses, Reports of nonlost-time and 40 months, lost-time back injuries (form retrospective data employment time and occupation): patient of the Occupational Safety collection lifting (OR and Health Administration) cohort nurses aides and attendants

Venning et al (93) $6 \quad 4306$ nursing aides and order- Any work-related injury or lies, and all registered nurses, complaint of discom officers, follow-up (registration health office) 12 months $(P \leq 0.05)$

Work (questionnaire, adjusted for job category, service area and previous history of reported back complaint): lifting

$\left(O R_{\text {lifiting patients }>10 \mathrm{~kg} \text { and } 21 / \text { day-less }}=2.19\right)(P \leq 0.05)$ response $93 \%$ 
Table 3. Continued.

\begin{tabular}{|c|c|c|c|c|c|}
\hline Authors & MQS & Study population & $\begin{array}{l}\text { Operationalization } \\
\text { of back pain }\end{array}$ & Follow-up & Results \\
\hline $\begin{array}{l}\text { Videman } \\
\text { et al }(103)^{d} \\
\text { Retrospective } \\
\text { cohort }\end{array}$ & 7 & $\begin{array}{l}2504 \text { surviving former athletes } \\
\text { in } 1985 \text { who had been } \\
\text { members of at least one } \\
\text { Finnish national team between } \\
\text { the years } 1920 \text { and } 1965 \text {, and } \\
\text { referents identified from the } \\
\text { register of men eligible for } \\
\text { military service, follow-up } \\
\text { response } 82 \%\end{array}$ & $\begin{array}{l}\text { 1. Having had back pain } \\
\text { which interfered with } \\
\text { work in the past } \\
\text { 2. Ever having had a } \\
\text { physician that diagnosed } \\
\text { sciatica (questionnaire) }\end{array}$ & $\begin{array}{l}20-65 \text { years, } \\
\text { depending on the } \\
\text { year in which } \\
\text { someone was } \\
\text { member of a } \\
\text { national team, } \\
\text { follow-up } \\
\text { measurement in } \\
1985\end{array}$ & 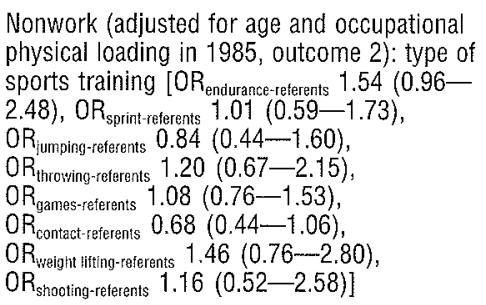 \\
\hline $\begin{array}{l}\text { Viikari-Juntura } \\
\text { et al (104)a }\end{array}$ & 5 & $\begin{array}{l}2900 \text { Finnish-speaking children } \\
\text { under the age of } 14 \text { years, } \\
\text { follow-up response } 28 \% \\
\text { Included in this study were } \\
180 \text { respondents who lived in } \\
\text { the Helsinki metropolitan } \\
\text { region, } 162 \text { of these } \\
\text { participated }\end{array}$ & $\begin{array}{l}\text { 1. Pain, ache, stiffness or } \\
\text { numbness in the low-back } \\
\text { region during the last } 12 \\
\text { months and a mean disability } \\
\text { index of } \geq 15 \text { at the last } \\
\text { follow-up in } 1986-1987 \\
2 \text {. Pain, ache, stiffness, or } \\
\text { numbness in the low back } \\
>7 \text { days or a mean disability } \\
\text { index of } \geq 15 \text { at the last } \\
\text { follow-up in 1986-1987 } \\
\text { (questionnaire) }\end{array}$ & $\begin{array}{l}32 \text { years, } 4 \\
\text { measurements }\end{array}$ & $\begin{array}{l}\text { Work among women (questionnaire } 1985, \\
\text { adjusted for alexithymia, social confidence, } \\
\text { fundamental education, sense of coherence } \\
\text { and twisted or bent torso, outcome } 1 \text { ): } \\
\text { Physical heaviness of work [0R } 0.02 \\
(0.00-1.90) \text { ] }\end{array}$ \\
\hline
\end{tabular}

a The article on this study does not make exactly clear when what was measured.

b Some of the results of the multivariable analyses in the article(s) on this study were disregarded in the data abstraction because it was only reported that a factor did not enter the model in stepwise modeling.

It is unclear if the analysis of risk factors in this study was really based on longitudinal data.

More results of this study, for example, with different operationalizations of back pain, are presented in a more-detailed version of this table, which is avallable from the author. The results that are presented were used in the assessment of the levels of evidence.

e The article on this study does not make exactly clear how the exposure of persons without complaints was assessed, and therefore it is not possible to judge if the conducted statistical analysis is correct.

t Variables concerning physical load at work were also examined in this study, but disregarded in the data abstraction because the information was derived from an open question in which it was asked to report the work-related stressful factors that were experienced, three at most.

- The results for work-related risk factors for a multivariable analysis including occupation in the article on this study were disregarded in the data abstraction because of the possibility of overadjustment due to the high correlation between occupation and work-related risk factors.

lifting and moving of patients. All the studies found a statistically significant positive effect for patient handling. According to these results there is moderate evidence that patient handling is a risk factor for back pain. The magnitude of the risk estimates (RR/OR) ranged from 1.7 to 2.7 .

\section{Bending and twisting}

Two high-quality studies reported on the effect of bending and twisting $(79,82)$. Both studies found a statistically significant positive effect for bending and twisting. According to these results there is strong evidence for a positive effect for bending and twisting. In the only study that presented an effect estimate, an odds ratio of 8.1 was found (79).

\section{Standing or walking}

Three high-quality studies determined the effect of prolonged standing or walking $(49,67,78)$. One found a statistically significant positive effect for prolonged standing or walking (67), and 1 found no effect (78). The third study only reported that no statistically significant effect was found (49). According to these inconsistent results, there is no evidence for an effect of prolonged standing or walking.

\section{Sitting}

Two high-quality studies $(49,67)$ studied the effect of prolonged sitting. One found a statistically significant negative effect for women only (67), and the other only reported that no statistically significant effect was found (49). Therefore, no evidence was found for an effect of prolonged sitting.

\section{Whole-body vibration}

Three high-quality studies and 1 low-quality study examined the effect of driving a car $(67,72,77,78)$ and a 4th high-quality study evaluated the effect of whole-body vibration (82). This latter study included a group of machine operators. The exposure of the back during machine operating is somewhat similar to that when driving a car, namely, low-frequency whole-body vibration in a seated position. Three high-quality studies found a statistically significant positive effect for this exposure $(77,78,82)$. 
Table 4. Summary of the case-referent studies on physical load and back pain. (MQS=methodological quality score based on items on validity and precision, $\mathrm{OR}=$ odds ratio, the corresponding $95 \%$ confidence interval is given in parentheses)

\begin{tabular}{|c|c|c|c|c|}
\hline Authors & MQS & Study population & Definition of cases and referents & Results \\
\hline $\begin{array}{l}\text { Nuwayhid } \\
\text { et al }(77)^{\mathrm{a}}\end{array}$ & 11 & $\begin{array}{l}\text { Over } 900 \text { fire fighters and } \\
1900 \text { fire officers assigned to } \\
142 \text { ladder and } 210 \text { engineer } \\
\text { companies; } N=115 \text { cases } \\
\text { (response } 62 \% \text { ) and } 109 \\
\text { referents (response } 75 \% \text { ) }\end{array}$ & $\begin{array}{l}\text { Cases: full-duty fire fighter, who reported } \\
\text { low-back pain to the New York City Fire } \\
\text { Department clinic, was evaluated by the } \\
\text { physician in charge and received } \geq 1 \text { day } \\
\text { medical leave during the } 6 \text {-month study } \\
\text { period; persons with previous low-back } \\
\text { pain, professional care or lost workdays } \\
\text { were excluded } \\
\text { Referents: full-duty fire fighters with no } \\
\text { previous low-back pain experience or with } \\
\text { earlier episodes that did not entail } \\
\text { professional care or loss of workdays }\end{array}$ & $\begin{array}{l}\text { Work (interview): physical exertion in index on-duty } \\
\text { period [0R } 3.71(1.94-7.10)] \text {, driving more miles } \\
\text { weekly ( } \mathrm{P} \leq 0.05) \\
\text { Work in index on-duty period (interview, adjusted for } \\
\text { rank, previous occupation, steps climbed, driving, } \\
\text { second job, off-duty activity): lift loads }>18 \mathrm{~kg} \\
{[0 \mathrm{R} 3.07(1.19-7.88)]} \\
\text { Nonwork in index off-duty period (interview): } \\
\text { exercise [OR } 0.73(0.43-1.25)] \text {, driving } \geq 25 \text { miles } \\
\text { [OR } 1.27(0.75-2.16)] \text {, at least one activity on } \\
\text { composite index of off-duty activities [OR } 0.41 \\
(0.23-0.73)]\end{array}$ \\
\hline $\begin{array}{l}\text { Punnett et al } \\
(79-81)^{\circ}\end{array}$ & 11 & $\begin{array}{l}\text { Employees of an automobile } \\
\text { assembly plant; } N=95 \text { cases } \\
\text { (response } 82 \% \text { ) and } 124 \\
\text { referents (response } 84 \% \text { ) }\end{array}$ & $\begin{array}{l}\text { Cases: new reports of back disorders } \\
\text { during the } 10 \text {-month study period and } \\
\text { who had symptoms in an interview } \\
\text { Referents: workers with no report of a } \\
\text { back disorder during the study period } \\
\text { and who had no symptoms or signs of } \\
\text { back disorders in an interview and an } \\
\text { examination and who had no medical } \\
\text { report for any back, neck, or shoulder } \\
\text { disorder within the } 90 \text { days preceding } \\
\text { the study }\end{array}$ & 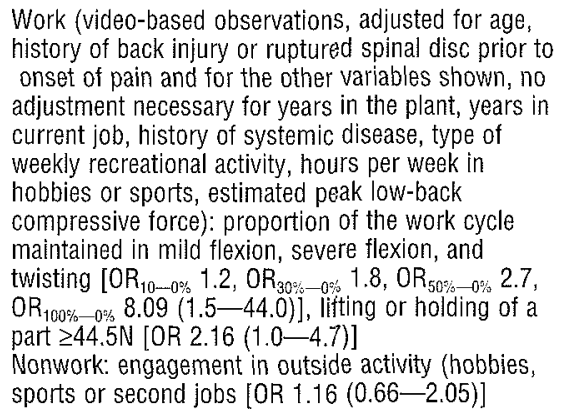 \\
\hline Ryden et al (101) & 7 & $\begin{array}{l}\text { Employees at a children's } \\
\text { hospital and health center; } \\
N=84 \text { cases and } 168 \text { matched } \\
\text { referents }\end{array}$ & $\begin{array}{l}\text { Cases: employees with reported low-back } \\
\text { injuries while employed at a children's } \\
\text { hospital and health center in 1983-1985 } \\
\text { Referents: selected from the same } \\
\text { population and matched by age, gender } \\
\text { and department or physical requirements } \\
\text { of the job }\end{array}$ & $\begin{array}{l}\text { Nonwork (employee health records, adjusted for age, } \\
\text { gender and department): exercise [OR } 1.33 \\
(0.44-2.84)]\end{array}$ \\
\hline
\end{tabular}

a The article on this study presents two effect estimates for lifting of loads, both adjusted for confounders. One of the presented estimates was lower and nonsignificant due to the inclusion of severity of alarms, a variable that was highly correlated with lifting of loads and therefore disregarded in the data abstraction.

b More results of this study are presented in a more-detailed version of this table, which is available from the author. The results that are presented were used in the assessment of the levels of evidence.

One high-quality study found a nonsignificant positive effect of driving a car for women only (67). According to these results there is strong evidence that whole-body vibration is a risk factor for back pain. The 2 studies that presented an effect estimate found an odds ratio of approximately $4.8(67,78)$.

\section{Heavy physical work}

Finally, there were several studies which did not study specific aspects of physical load, but evaluated physical activity in the workplace in general. Five high and 6 lowquality studies reported on the effect of this exposure (27, $29,38,60,61,73,74,77,94,96,104)$. Since 4 of the high-quality studies only reported that no statistically significant effect was found $(29,38,61,73)$, assessment of the consistency of the evidence for this exposure was based on the combined results of the 1 high- and the 5 low-quality studies that reported an estimate or the direction of the effect found. One study found a nonsignificant negative effect for heavy physical work (104). Five studies showed that a high level of physical activity had a statistically significant positive effect $(60,74,77,94$,
96). According to these results there is moderate evidence that a high level of physical activity is a risk factor for back pain. The magnitude of the risk estimates (RR or OR) ranged from 1.5 to 9.8 .

The studies differed somewhat in the timing of the exposure. The effect of a cumulative work load (94), the effect of short-term physical exertion (77) and current physical work-load at baseline $(60,74,96)$ were examined. It was, however, not possible to draw separate conclusions for the cumulative and short-term effects of heavy physical work.

\section{Sensitivity analysis}

For manual materials handling, patient handling, bending and twisting, whole-body vibration, and heavy physical work it was concluded that there was (strong or moderate) evidence of an effect. Considering all the studies that found a nonsignificant effect for these exposures to indicate no effect did not change the conclusions for manual materials handling, patient handling, bending and twisting, or whole-body vibration. For heavy physical work this assumption would mean that 6 studies 
indicated no effect, and 5 studies indicated a positive effect, and therefore the conclusion would be drawn that there is no evidence for an effect of heavy physical work, due to inconsistent findings.

\section{Physical load during leisure time}

\section{Sports}

Six high- and 5 low-quality studies examined the effect of sports activities $(52,60,62,73,76-78,82,87,96$, 101). Two high-quality studies that only reported that no statistically significant effect was found and 1 high-quality study that reported a significant effect, but did not show the direction of the effect, were excluded from the evaluation of the evidence $(52,73,78)$. Of the remaining high-quality studies, one found a statistically significant positive effect for physical activity (82), one found a statistically significant negative effect among men and no effect among women (62), and one found a nonsignificant negative effect (77). According to these inconsistent results there is no evidence for an effect of sports activities.

\section{Total physical activity during leisure time}

Four high-quality studies and 1 low-quality study examined the effect of total physical activity during leisure time $(62,75,77,86,100)$. Total physical activity during leisure time includes sports activities and other physical activities such as gardening, walking, traveling to and from work, and housework. One high-quality study found a statistically significant negative effect for off-duty activities (77). The other high-quality studies only reported that no statistically significant effect was found (62, $86,100)$.

One high-quality study and 2 low-quality studies examined the effect of physical activity, but did not make it explicitly clear whether this only involved sports or exercise or also included other leisure-time physical activities. The high-quality study only reported that no statistically significant effect was found $(29,46)$. According to these results there is no evidence for an effect of total physical activity during leisure time.

\section{Specific sports and physical activities during leisure time}

Four studies determined the effect of participation in specific sports, namely, golf (49), cycling (96) and athletic training $(55,103)$. No evidence was found that any of these were risk factors because either there was only 1 study available $(49,96)$ or the findings were inconsistent $(55,103)$.
Two high-quality studies focused on the effect of driving a car during leisure time. One study (82) found no statistically significant effect for annual car driving (total kilometers) and the other found no effect of driving more than 25 miles $(40 \mathrm{~km})$ in the off-duty period before the report of low-back pain (77). According to these results there is no evidence for an effect of driving a car during leisure time.

\section{Discussion}

\section{Selection of studies}

Although a systematic approach with a large variation of key words was used and references of selected articles were screened to identify all the available literature, the possibility of selection and publication bias cannot be excluded.

An important difference between this review and previously published reviews on the same topic is the exclusion of studies with a cross-sectional design. The main argument for the exclusion of this type of study is that temporality, the only unarguable and therefore necessary criterion for causality (105), is not met in cross-sectional studies, in which exposure and outcome are assessed simultaneously. Cohort studies were only included if the follow-up period was at least 1 year. The major reason for this restriction was that the follow-up needs to be long enough to record sufficient cases of back pain.

In addition, the choice was made to include studies with a fairly broad spectrum of outcome measures. This can lead to contradictory findings if the effect of an exposure is specific to certain categories of the outcome but, on the other hand, maximum power can be achieved (106). Since symptoms, reports of back pain, sick leave, medical consultation, or treatment and disability due to back pain are all part of a continuum, it was assumed that any factor that causes the back pain itself will have an effect on all these outcome measures. However, some factors may not only affect the development, but also the prognosis of back pain. Eventually, in most studies the assessment of the outcome was based on symptom re porting, mainly due to the lack of generally accepted criteria for an objective clinical diagnosis of back pain. Unfortunately, the operationalization of back pain based on the symptom reporting used in the included studies did not make it possible to examine the risk factors for different groups of back pain, classified based on characteristics such as the duration, frequency, intensity, and localization of the pain. (107) Studies with a diagnosed herniated lumbar disc as the outcome measure were excluded, because a separate review of risk factors for this more homogeneous disease entity was regarded to be more appropriate. 


\section{Assessment of evidence}

The main difference between this review and previously published reviews on the same topic is the application of a systematic approach which includes explicitly defined criteria, on which the conclusions on the strength of the evidence were based. The review could only be qualitative, because, in many of the studies reviewed in this paper, quantitative measures of effect were missing for at least some of the exposures of interest. Moreover, the methods used to measure exposure are often so different that it is not possible to compare the evaluated contrasts of exposure.

Scoring the quality of a study plays an important role in the assessment of the strength of the evidence. However, it is only meant to distinguish between high- and low-quality studies. Criteria lists adapted from lists used in the clinical literature and in other reviews of observational studies were used to assess the methodological quality of the studies. As in the clinical literature, it is still unclear which items are especially important because of the influence of bias (16). One of the specific problems encountered in this review of observational epidemiologic studies, compared with reviews of clinical trials which usually evaluate only 1 contrast, is the fact that the relatively broad objective of this review and most of the evaluated studies resulted in a relatively nonspecific list of criteria. As the evidence for more than 1 exposure per study was evaluated, it was not possible to include a criterion on the power of each individual study. The most appropriate solution to the problem raised would be a series of reviews, each focusing on 1 specific risk factor. Only for such reviews could really specific criteria lists be developed. However, an advantage of a review like ours, with its broader focus over reviews with a more specific focus, is that it offers the possibility to compare the evidence found for different risk factors.

Criterion 5, which only pertains to the list for casereferent studies, may sound contradictory, because the exclusion of subjects with recent back pain from the reference group may be considered incompatible with the requirement that cases and referents have to be drawn from the same population. The criterion reflects that, on one hand, it is important that cases and referents be drawn from the same population and selected independently of their exposure status to make sure that the referents are representative of the source population with respect to exposure. While, on the other hand, there has to be a clear contrast between cases and referents with respect to the disease in question. For recurrent outcomes like back pain this is more difficult than for diseases like cancer. With the exclusion of subjects with low-back pain during the previous 90 days from the reference group, one can make sure that there is a real contrast in disease status between cases and referents.
Another problem which arises from the rating system applied in this review is that the synthetic approach can give a false impression of consistency across study results, because all the studies were prone to a common systematic error (106), such as (residual) confounding. With regard to the definition of the levels of evidence applied in this review, it could be argued that the conclusion could be limited evidence instead of no evidence if only 1 study evaluated the exposure. This procedure was decided against because the consistency of results, an important aspect of the definition of the other levels of evidence in this review, cannot be evaluated on the basis of 1 single study.

In spite of the limitations of defining levels of evidence, it was thought that this approach was appropriate in the present qualitative review. One important advantage is that the reader is given a lot of insight into the process used to assess the evidence. And there is also the possibility to repeat the analysis and to examine how the conclusions are influenced if slight changes are made in the assessment of the findings or the methodological quality of the studies. The sensitivity analysis already included the effect of a different way of dealing with nonsignificant findings. Another means of assessing the methodological quality of a study is to use another cutoff point for the assessment of high-quality studies. The use of a cut-off point of $40 \%$ for the assessment of highquality studies leads to an increase in the number of highquality studies, which, in turn, leads to strong instead of moderate evidence for the effect of patient handling and heavy physical work. This change would not influence the conclusions with regard to the other exposures, and the use of a cut-off point of $60 \%$ does not affect the conclusion for any exposure. Moreover, the results of the review are rather insensitive to the exclusion of the items on the assessment of different exposures (items 8-13) from the criteria list for the methodological quality assessment. Thus the conclusions drawn in this review are also rather insensitive to a slightly different assessment of high- and low-quality studies.

\section{Quality of the studies}

An examination of the scoring of studies on the various items shows that all the studies had a clearly defined objective. However, this objective did not always include an examination of the exposures of interest in this review $(53,55,73,86,104)$. Twenty percent of the studies failed to describe the main features of the study populations, and very few studies used standardized methods of acceptable quality for the assessment of physical load at work and back pain. Furthermore, the rate of participation at base line was less than $80 \%$ in approximately twothirds of the studies. Some $60 \%$ of the cohort studies collected data on the outcome at least every 3 months, most 
of which used registered data, and many of these studies did not report on the loss to follow-up in their registration system. Three cohort studies did not collect data on the occurrence of back pain for at least 1 year, although the follow-up period was at least 1 year. These studies used the point prevalence of back pain at the end of follow-up as an outcome measure $(46,75,94)$. Due to the low number of case-referent studies, it was not possible to present data on the scoring of the specific criteria for this study design.

There are also a few aspects of the quality of the studies that were not included in the criteria list, but were observed during the scoring of the studies. Hardly any studies included repeated measurements of the exposure, although there were many studies with an extremely long follow-up period during which the exposure easily could have changed considerably $(27,60,61,72,100,103)$. Moreover, some of these studies did not assess the occurrence of back pain for the entire follow-up period (61, $62,100,103)$. The studies included in the review do not provide much insight into the effect of adjustment for certain covariates, because only a few studies showed the effect estimate for a certain exposure with and without adjustment for covariates $(79,102,103)$.

\section{Evidence for aspects of physical load during work as risk factors for back pain}

For manual materials handling, bending and twisting, and whole-body vibration it was concluded that there was strong evidence for an effect. For patient handling and heavy physical work it was concluded that there was moderate evidence for an effect. To exclude the possibility of a false impression of consistency of the findings, the potential lack of controlling for likely important confounders was examined for these exposures. In general, only a few studies on lifting, bending and twisting, driving or whole-body vibration, and heavy physical work had adjusted for other physical and psychosocial factors at work. None of the studies had adjusted for physical load during leisure time. The effect of driving a car has been attributed to whole-body vibration on one hand and to prolonged sitting on the other. However, none of the studies on driving a car or whole-body vibration had adjusted for prolonged sitting.

In the sensitivity analysis, instead of moderate evidence, no evidence was found for the effect of heavy physical work. For this exposure 6 studies only reported that no statistically significant effects were found. However, it is debatable whether these studies can lead to the conclusion that there is no effect. In the original papers of 4 studies $(29,38,73,104)$ it was emphasized that physical work load factors could not be effectively studied, due to the method of selection of the subjects in combination with the nonspecific method used for the assessment of the exposure. In the 2 other studies, the absence of an effect could be explained by the relatively long follow-up period, which probably coincided with changes in exposure $(27,61)$. In addition, the effect of physical load was analyzed separately for white- and blue-collar workers, and the occurrence of back pain was only assessed for the last 12 months of the 10-year follow-up period (61).

For standing or walking, it was concluded that there was no evidence because of the contradictory findings. The only study that found an effect had only adjusted for prior back pain (67), and the study in which no effect was found had also adjusted for other aspects of physical load at work (78). However, it is debatable whether this difference in study results indicates the presence of confounding. The absence of an effect in the second study could also have been caused by the combination of a population of persons with similar work conditions and a badly defined measure of exposure, namely, a yes-no question about frequent prolonged standing. No evidence was found for an effect of sitting because the available information was too limited.

Prolonged sitting and standing are both assumed to be a risk factor for back pain because, among other things, they are both aspects of static load. Prolonged working in awkward postures is also an aspect of static load. However, with regard to sitting, standing, and working in awkward postures, none of the studies adequately evaluated the static effect of these exposures. Appropriate measurements for static load of the trunk, which should preferably be included in future studies, are the total duration of working continuously in a certain posture for longer than a certain period of time and the number of changes in posture during a workday for all parts of the body separately and combined.

\section{Evidence for aspects of physical load during leisure time as risk factors for back pain}

There appeared to be no evidence for an effect of sports, due to inconsistent findings. The available studies differed in their individual definition of back pain, the composition of the study population, the control for confounding, and also the time-period between the measurement of exposure and back pain. Moreover, no evidence was found for an effect of total physical activity during leisure time, various specific sports, or other physical activities during leisure time.

One important aspect of all the studies on physical activity during leisure time was that the operationalization of physical activity in the studies differed and was, in general, not very specific. It has been concluded that in epidemiologic studies on the role of physical activity in the etiology of diseases, the type, intensity, frequency, and duration of physical activity should be addressed and the measurement method should be in agreement with the disease in question (108). The methods used in 
most of the studies included in this review do not meet these criteria. Therefore, it may be worthwhile to develop new methods to measure physical load during leisure time and to evaluate more adequately the effect of this exposure. If this process results in a method involving operationalizations that correspond to the measurements of physical load at work, it may also enhance the possibility to study these exposures simultaneously.

\section{Comparison with the results of previous reviews}

It is interesting to see how the conclusions of this review compare with the conclusions of 2 other recently published reviews on the same topic $(9,11)$. With regard to the work-related physical factors, it appears that there is no significant difference in the conclusions. Both reviews $(9,11)$ conclude that there is evidence for an effect of lifting, bending and twisting, whole-body vibration, and heavy physical work. Burdorf \& Sorock (11) also concluded that the evidence for exercise and sports is contradictory.

\section{Concluding remarks and recommendations}

According to the literature reviewed in this paper, there is moderate evidence that patient handling and heavy physical work are risk factors for back pain, and strong evidence that manual materials handling, bending and twisting, and whole-body vibration at work are risk factors for back pain. However, to determine the priorities for intervention in the workplace, it is also important to be aware of the magnitude of the effect of the various risk factors. For the purpose of evaluation, future studies should include quantitative measurements of exposure and report effect measures that reflect the risk of equivalent levels of contrast in exposure, measured in a comparable way. This procedure would make it possible to quantify the role of different risk factors in a meta-analysis.

For standing or walking, sitting, and various aspects of physical load during leisure time it was concluded that there was no evidence of an effect. For these risk factors, further well-designed research is needed if a conclusion is to be drawn on the presence or absence of an effect of these factors. With regard to physical load at work, adequate measures of static load must be related to the occurrence of back pain. Appropriate methods must also be developed to measure the relevant aspects of physical load during leisure time, and the combination of exposure to physical load during work and leisure time should also be addressed.

The results of this review are rather insensitive to slight changes in the assessment of the findings and methodological quality of the studies. The application of a systematic approach, adapted from the evaluation of randomized controlled trials on intervention for back pain, in the review of observational epidemiologic studies is shown to be worthwhile, not withstanding the problems encountered.

\section{References}

1. Andersson GBJ, Pope MH, Frymoyer JW, Snook S. Epidemiology and cost. In: Pope MH, Andersson GBJ, Frymoyer JW, Chaffin DB, editors. Occupational low back pain: assessment, treatment and prevention. St Louis (MO): Mosby-Year Book, 1991:95-113.

2. Frymoyer JW. Back pain and sciatica. N Engl J Med 1988:318(5):291-300.

3. Frymoyer JW, Cats-Baril WL. An overview of the incidences and costs of low back pain. Orthop Clin North Am 1991;22(2):263-71.

4. Raspe HH. Back pain. In: Silman AJ, Hochberg MC, editors. Epidemiology of the rheumatic diseases. New York (NY): Oxford University Press, 1993:330 - 74.

5. Picavet HSJ, Schouten JSAG, Smit HA. Prevalenties en consequenties van lage rugklachten in het MORGEN-project 1993-1995. Bilthoven: Rijksinstituut voor volksgezondheid en milieu, 1996.

6. Van Tulder MW, Koes BW, Bouter LM. A cost-of-illness study of back pain in the Netherlands. Pain 1995;62:233 - 40 .

7. Hildebrandt VH. Back pain in the working population: prevalence rates in Dutch trades and professions. Ergonomics 1995;38(6):1283-98.

8. Shelerud R. Epidemiology of occupational low back pain. Occup Med 1998;13(1):1-22.

9. Bernard BP, editor. Musculoskeletal disorders and workplace factors: a critical review of epidemiologic evidence for workrelated musculoskeletal disorders of the neck, upper extremity, and low back. Cincinnati (OH): National Institute for Occupational Safety and Health, US Department of Health and Human Services, 1997.

10. Bongers PM, de Winter CR, Kompier MAJ, Hildebrandt VH. Psychosocial factors at work and musculoskeletal disease [review]. Scand J Work Environ Health 1993;19(5):297-312.

11. Burdorf A, Sorock G. Positive and negative evidence of risk factors for back disorders [review]. Scand J Work Environ Health 1997;23(4):243-56.

12. Frank JW, Kerr MS, Brooker AS, DeMaio SE, Maetzel A, Shannon HS, et al. Disability resulting from occupational low back pain, part I: what do we know about primary prevention? A review of the scientific evidence on prevention before disability begins. Spine 1996;21(24):2908-17.

13. Garg A, Moore JS. Epidemiology of low-back pain in industry. Occup Med 1992;7(4):593-608.

14. Kelsey JL, Golden AL. Occupational and workplace factors associated with low back pain. Occup Med 1988;3(1):7-16.

15. Riihimäki $H$. Low-back pain, its origin and risk indicators [review]. Scand J Work Environ Health 1991;17(2):81-90.

16. van Tulder MW, Assendelft WJ, Koes BW, Bouter LM. Method guidelines for systematic reviews in the Cochrane Collaboration Back Review Group for Spinal Disorders. Spine 1997;22(20):2323-30.

17. Kumar S. Cumulative load as a risk factor for back pain. Spine 1990;15(12):1311-6.

18. McGill SM. The biomechanics of low back injury: implications on current practice in industry and the clinic. J Biomech 1997;30(5):465-75.

19. van Tulder MW, Koes BW, Bouter LM. Conservative treat- 
ment of acute and chronic nonspecific low back pain: a systematic review of randomized controlled trials of the most common interventions. Spine 1997;22(18):2128--56.

20. Borghouts JAJ, Koes BW, Bouter LM. The clinical course and prognostic factors of non-specific neck pain: a systematic review. Pain 1998;77:1-13.

21. Stock SR. Workplace ergonomic factors and the development of musculoskeletal disorders of the neck and upper limbs: a meta-analysis. Am J Ind Med 1991;19:87-107.

22. Greenland $\mathrm{S}$. Modeling and variable selection in epidemiologic analysis. Am J Public Health 1989;79(3):340 -9.

23. Bigos SJ, Bowyer O, Braen G, et al. Acute low back problems in adults. Rockville (MD): Agency for Health Care Policy and Research, Public Health Service, US Department of Health and Human Services, December 1994. Clinical practice guideline no 14. AHCPR publication no 95-0642.

24. Lang JM, Rothman KJ, Cann CI. That confounded P-value. Epidemiology 1998;9(1):7---8.

25. Åstrand NE, Isacsson SO. Back pain, back abnormalities, and competing medical, psychological, and social factors as predictors of sick leave, early retirement, unemployment, labour turnover and mortality: a 22 year follow up of male employees in a Swedish pulp and paper company. Br J Ind Med 1988;45(6):387--95.

26. Åstrand NE. Medical, psychological, and social factors associated with back abnormalities and self reported back pain: a cross sectional study of male employees in a Swedish pulp and paper industry. Br J Ind Med 1987;44(5):327-36.

27. Biering-Sørensen F, Hansen FR, Schroll M, Runeborg O. The relation of spinal $x$-ray to low-back pain and physical activity among 60-year-old men and women. Spine 1985;10(5):44551.

28. Biering-Sørensen $F$, Thomsen CE, Hilden J. Risk indicators for low back trouble. Scand J Rehabil Med 1989;21(3):1517.

29. Biering-Sørensen F, Thomsen C. Medical, social and occupational history as risk indicators for low-back trouble in a general population. Spine 1986;11(7):720-5.

30. Biering-Sørensen F. A one-year prospective study of low back trouble in a general population: the prognostic value of low back history and physical measurements. Dan Med Bull 1984;31(5):362-75.

31. Biering-S $\varnothing$ rensen F. Physical measurements as risk indicators for low-back trouble over a one-year period. Spine 1984;9(2):106-19.

32. Biering-Sørensen F, Hilden J. Reproducibility of the history of low-back trouble. Spine 1984;9(3):280--6.

33. Biering-Sørensen F. A prospective study of low back pain in a general population, I: occurrence, recurrence and aetiology. Scand J Rehabil Med 1983;15(2):71-9.

34. Biering-Sørensen F. A prospective study of low back pain in a general population, II: location, character, aggravating and relieving factors. Scand J Rehabil Med 1983;15(2):81-8.

35. Biering-Sørensen F. A prospective study of low back pain in a general population, III: medical service-work consequence. Scand J Rehabil Med 1983;15(2):89-96.

36. Biering-Sørensen $F$. Low back trouble in a general population of 30-, 40-, 50-, and 60-year-old men and women. Study design, representativeness and basic results. Dan Med Bull 1982;29(6):289_-99.

37. Bigos SJ, Battié MC, Spengler DM, Fisher LD, Fordyce WE, Hansson T, et al. A longitudinal, prospective study of industrial back injury reporting. Clinical Orthop 1992;(279):2134
38. Bigos SJ, Battié MC, Spengler DM, Fisher LD, Fordyce WE Hansson TH, et al. A prospective study of work perceptions and psychosocial factors affecting the report of back injury [published erratum appears in Spine 1991 Jun;16(6):688] Spine 1991;16(1):1-6.

39. Bigos SJ, Battié MC, Fisher LD, Hansson TH, Spengler DM, Nachemson AL. A prospective evaluation of preemployment screening methods for acute industrial back pain. Spine 1992;17(8):922-6.

40. Battié MC, Hansson T, Bigos S, Zeh J, Fisher L, Spengler D. B-scan ultrasonic measurement of the lumbar spinal canal as a predictor of industrial back pain complaints and extended work loss. J Occup Med 1993;35(12):1250-5

41. Battié MC, Bigos SJ, Fisher LD, Spengler DM, Hansson TH Nachemson AL, et al. The role of spinal flexibility in back pain complaints within industry: a prospective study. Spine 1990;15(8):768-73.

42. Battié MC, Bigos SJ, Fisher LD, Spengler DM, Hansson TH, Nachemson AL, et al. Anthropometric and clinical measures as predictors of back pain complaints in industry: a prospective study. J Spinal Disord 1990;3(3):195-204.

43. Battié MC, Bigos SJ, Fisher LD, Hansson TH, Nachemson $\mathrm{AL}$, Spengler DM, et al. A prospective study of the role of cardiovascular risk factors and fitness in industrial back pain complaints. Spine 1989;14(2):141-7.

44. Battié MC, Bigos SJ, Fisher LD, Hansson TH, Jones ME, Wortley MD. Isometric lifting strength as a predictor of industrial back pain reports. Spine 1989;14(8):851-6.

45. Fordyce WE, Bigos SJ, Battié MC, Fisher LD. MMPI scale 3 as a predictor of back injury report: what does it tell us? Clin J Pain 1992;8(3):222—6.

46. Brattberg $\mathrm{G}$. The incidence of back pain and headache among Swedish school children. Qual Life Res 1994;3(SI):S27-31.

47. Brattberg G. Back pain and headache in Swedish schoolchildren: a longitudinal study. Pain Clinic 1993;6(3):157-62.

48. Brattberg G, Wickman V. Prevalence of back pain and headache in Swedish school children: a questionnaire survey. Pain Clinic 1992;5(4):211-20.

49. Burdorf A, van der Steenhoven GA, Tromp-Klaren EG. A one-year prospective study on back pain among novice golfers. Am J Sports Med 1996;24(5):659-64.

50. Chaffin DB. Human strength capability and low-back pain. J Occup Med 1974;16(4):248—54.

51. Chaffin DB, Park KS. A longitudinal study of low-back pain as associated with occupational weight lifting factors. Am Ind Hyg Assoc J 1973;34(12):513-25.

52. Klaber Moffett JA, Hughes GI, Griffiths P. A longitudinal study of low back pain in student nurses. Int J Nurs Stud 1993;30(3):197-212.

53. Kuh DJ, Coggan D, Mann S, Cooper C, Yusuf E. Height, occupation and back pain in a national prospective study. $\mathrm{Br} J$ Rheumatol 1993;32(10):911-6.

54. Wadsworth ME, Mann SL, Rodgers B, Kuh DJ, Hilder WS Yusuf EJ. Loss and representativeness in a 43 year follow up of a national birth cohort. J Epidemiol Community Health 1992;46(3):300-4.

55. Kujala UM, Taimela S, Oksanen A, Salminen JJ. Lumbar mobility and low back pain during adolescence: a longitudinal three-year follow-up study in athletes and controls. Am J Sports Med 1997;25(3):363-8

56. Kujala UM, Taimela S, Erkintalo M, Salminen JJ, Kaprio J. Low-back pain in adolescent athletes. Med Sci Sports Exerc 1996;28(2): $165-70$

57. Kujala UM, Taimela S, Salminen JJ, Oksanen A. Baseline 
anthropometry, flexibility and strength characteristics and future low-back pain in adolescent athletes and nonathletes: a prospective one-year follow-up study. Scand J Med Sci Sports 1994:4:200-5.

58. Kujala UM, Salminen JJ, Taimela S, Oksanen A, Jaakkola L. Subject characteristics and low back pain in young athletes and nonathletes. Med Sci Sports Exerc 1992;24(6):627-32.

59. Salminen JJ, Pentti J, Terho P. Low back pain and disability in 14-year-old schoolchildren. Acta Paediatr 1992;81(12):1035-9.

60. Kujala UM, Taimela S, Viljanen T, Jutila H, Viitasalo JT, Videman T, et al. Physical loading and performance as predictors of back pain in healthy adults: a 5-year prospective study. Eur J Appl Physiol Occup Physiol 1996;73(5):452-8.

61. Leino PI, Hänninen V. Psychosocial factors at work in relation to back and limb disorders. Scand J Work Environ Health 1995;21(2):134-42.

62. Leino PI. Does leisure time physical activity prevent low back disorders? A prospective study of metal industry employees. Spine 1993;18(7):863-71.

63. Leino P, Magni G. Depressive and distress symptoms as predictors of low back pain, neck-shoulder pain, and other musculoskeletal morbidity: a 10-year follow-up of metal industry employees. Pain 1993;53(1):89-94.

64. Leino P. Symptoms of stress predict musculoskeletal disorders. J Epidemiol Community Health 1989;43(3):293-300.

65. Leino P, Hasan J, Karppi SL. Occupational class, physical workload, and musculoskeletal morbidity in the engineering industry. Br J Ind Med 1988;45(10):672—81.

66. Leino P, Aro S, Hasan J. Trunk muscle function and low back disorders: a ten-year follow-up study. J Chronic Dis 1987;40(4):289-96.

67. Macfarlane GJ, Thomas E, Papageorgiou AC, Croft PR, Jayson MI, Silman AJ. Employment and physical work activities as predictors of future low back pain. Spine 1997;22(10):1143-9.

68. Papageorgiou AC, Macfarlane GJ, Thomas E, Croft PR, Jayson MI, Silman AJ. Psychosocial factors in the workplace-do they predict new episodes of low back pain? Evidence from the South Manchester Back Pain Study. Spine 1997;22(10):1137-42.

69. Papageorgiou AC, Croft PR, Thomas E, Ferry S, Jayson MI, Silman AJ. Influence of previous pain experience on the episode incidence of low back pain: results from the South Manchester Back Pain Study, Pain 1996;66(2-3):181—5.

70. Croft PR, Papageorgiou AC, Ferry S, Thomas E, Jayson MI, Silman AJ. Psychologic distress and low back pain. Evidence from a prospective study in the general population. Spine 1995;20(24):2731-7.

71. Papageorgiou AC, Croft PR, Ferry S, Jayson MI, Silman AJ Estimating the prevalence of low back pain in the general population: evidence from the South Manchester Back Pain Survey. Spine 1995;20(17):1889-94.

72. Manninen $P$, Riihimäki H, Heliövaara M. Incidence and risk factors of low-back pain in middle-aged farmers. Occup Med 1995;45(3):141-6.

73. Mannion AF, Dolan P, Adams MA. Psychological questionnaires: do "abnormal" scores precede or follow first-time low back pain? Spine 1996;21(22):2603-11.

74. Mooney V, Kenney K, Leggett S, Holmes B. Relationship of lumbar strength in shipyard workers to workplace injury claims. Spine 1996;21(17):2001-5.

75. Muramatsu N, Liang J, Sugisawa $H$. Transitions in chronic low back pain in Japanese older adults: a sociomedical per- spective. J Gerontol Series B, Psychological Sciences \& Social Sciences 1997;52(4):S222_-34.

76. Niedhammer I, Lert F, Marne MJ. Back pain and associated factors in French nurses. Int Arch Occup Environ Health 1994;66(5):349—57.

77. Nuwayhid IA, Stewart W, Johnson JV. Work activities and the onset of first-time low back pain among New York City fire fighters. Am J Epidemiol 1993;137(5):539 - 48.

78. Pietri F, Leclerc A, Boitel L, Chastang J-F, Morcet J-F, Blondet M. Low-back pain in commercial travelers. Scand J Work Environ Health 1992;18(1):52-8.

79. Punnett L, Fine LJ, Keyserling WM, Herrin GD, Chaffin DB. Back disorders and nonneutral trunk postures of automobile assembly workers. Scand J Work Environ Health 1991;17(5):337-46.

80. Keyserling WM, Punnett L, Fine LJ. Trunk posture and back pain: Identification and control of occupational risk factors. Appl Ind Hyg 1988;3(3):87—92.

81. Keyserling WM. Postural analysis of the trunk and shoulders in simulated real time. Ergonomics 1986;29(4):569—83.

82. Riihimäki H, Viikari-Juntura E, Moneta G, Kuha J, Videman $T$, Tola $S$. Incidence of sciatic pain among men in machine operating, dynamic physical work, and sedentary work: a three-year follow-up. Spine 1994;19(2):138-42.

83. Pietri-Taleb F, Riihimäki H, Viikari-Juntura E, Lindström K, Moneta GB. The role of psychological distress and personality in the incidence of sciatic pain among working men. Am J Public Health 1995;85(4):541-5.

84. Riihimäki H, Tola S, Videman T, Hänninen K. Low-back pain and occupation: a cross-sectional questionnaire study of men in machine operating, dynamic physical work, and sedentary work. Spine 1989;14(2):204—9.

85. Rohrer MH, Santos-Eggimann B, Paccaud F, Haller-Maslov E. Epidemiologic study of low back pain in 1398 Swiss conscripts between 1985 and 1992. Eur Spine J 1994;3(1):2-7.

86. Rossignol M, Lortie M, Ledoux E. Comparison of spinal health indicators in predicting spinal status in a 1-year longitudinal study. Spine 1993;18(1):54-60.

87. Salminen JJ, Erkintalo M, Laine M, Pentti J. Low back pain in the young. A prospective three-year follow-up study of subjects with and without low back pain. Spine 1995;20(19):2101-7; discussion 2108.

88. Salminen JJ, Oksanen A, Maki P, Pentti J, Kujala UM. Leisure time physical activity in the young: correlation with lowback pain, spinal mobility and trunk muscle strength in 15year-old school children. Int J Sports Med 1993;14(7):40610.

89. Salminen JJ, Erkintalo-Tertti MO, Paajanen HE. Magnetic resonance imaging findings of lumbar spine in the young: correlation with leisure time physical activity, spinal mobility, and trunk muscle strength in 15-year-old pupils with or without low-back pain. J Spinal Disord 1993;6(5):386-91.

90. Salminen JJ, Maki P, Oksanen A, Pentti J. Spinal mobility and trunk muscle strength in 15-year-old schoolchildren with and without low-back pain. Spine 1992;17(4):405-11.

91. Smedley J, Egger P, Cooper C, Coggon D. Prospective cohort study of predictors of incident low back pain in nurses. BMJ 1997;314(7089):1225-8.

92. Smedley J, Egger P, Cooper C, Coggon D. Manual handling activities and risk of low back pain in nurses. Occup Environ Med 1995;52(3):160-3.

93. Venning PJ, Walter SD, Stitt LW. Personal and job-related factors as determinants of incidence of back injuries among nursing personnel. J Occup Med 1987;29(10):820—5. 
94. Bergenudd H, Nilsson B. Back pain in middle age; occupational workload and psychologic factors: an epidemiologic survey. Spine 1988;13(1):58-60.

95. Chaffin DB, Herrin GD, Keyserling WM. Preemployment strength testing: an updated position. J Occup Med 1978;20(6):403-8.

96. Gyntelberg F. One year incidence of low back pain among male residents of Copenhagen aged 40-59. Dan Med Bull 1974;21(1):30-6.

97. Gyntelberg F, Ohlsen K. Physical fitness and serum cholesterol in Copenhagen males aged $40-59$. Scand $\mathbf{J}$ Clin Lab Invest 1973;32(3):211-6.

98. Liles DH, Deivanayagam S, Ayoub MM, Mahajan P. A job severity index for the evaluation and control of lifting injury. Hum Factors 1984;26(6):683-93.

99. Ayoub MM, Selan JL, Liles DH. An ergonomics approach for the design of manual materials-handling tasks. Hum Factors 1983;25(5):507-15.

100. Ready AE, Boreskie SL, Law SA, Russell R. Fitness and lifestyle parameters fail to predict back injuries in nurses. Can J Appl Physiol 1993;18(1):80-90.

101. Ryden LA, Molgaard CA, Bobbitt S, Conway J. Occupational low-back injury in a hospital employee population: an epidemiologic analysis of multiple risk factors of a high-risk occupational group. Spine 1989;14(3):315-20.

102. Stobbe TJ, Plummer RW, Jensen RC, Attfield MD. Incidence of low back injuries among nursing personnel as a function of patient lifting frequency. J Safety Res 1988;19(1):21-8.

103. Videman T, Sarna S, Battié MC, Koskinen S, Gill K, Paananen $\mathrm{H}$, et al. The long-term effects of physical loading and exercise lifestyles on back-related symptoms, disability, and spinal pathology among men. Spine 1995;20(6):699-709.

104. Viikari-Juntura E, Vuori J, Silverstein BA, Kalimo R, Kuosma $\mathrm{E}$, Videman T. A life-long prospective study on the role of psychosocial factors in neck-shoulder and low-back pain. Spine 1991;16(9):1056-61.

105. Rothman KJ, Greenland S. Causation and causal inference. In: Rothman KJ, Greenland S, editors. Modern epidemiology. Philadelphia (MA): Lippincott-Raven Publishers, 1998:728.

106. Greenland S. Meta-analysis. In: Rothman KJ, Greenland S, editors. Modern epidemiology. Philadelphia (MA): Lippincott-Raven Publishers, 1998:643-673.

107. Riihimäki H. Methodological problems in assessing health outcome in epidemiologic studies of musculoskeletal disorders. In: Problems and progress in assessing physical load and musculoskeletal disorders: Tagungsbericht 10. Berlin: Schriftenreihe der Bundesanstalt für Arbeitsmedizin, 1996:7-12.

108. Pols MA, Peeters PHM, Kemper HCG, Grobbee DE. Methodological aspects of physical activity assessment in epidemiological studies. Eur J Epidemiol 1998;14(1):63—70.

Received for publication: 8 January 1999 


\section{Appendix}

\section{Methodological quality assessment: criteria lists for assessment of the methodological quality of prospective and historical cohort studies and case-referent studies}

\begin{tabular}{|c|c|c|}
\hline Criterion & Designa & $\mathrm{I}, \mathrm{V} / \mathrm{Pb}^{\mathrm{b}}$ \\
\hline \multicolumn{3}{|l|}{ Objective of the study } \\
\hline 1. Positive if the study had a clearly defined objective & $\mathrm{CH} / \mathrm{CR}$ & I \\
\hline \multicolumn{3}{|l|}{ Study population } \\
\hline $\begin{array}{l}\text { 2. Positive if the main features (description of the sampling frame, distribution of the population according to age } \\
\text { and gender) of the study population were described }\end{array}$ & $\mathrm{CH} / \mathrm{CR}$ & 1 \\
\hline 3. Positive if the participation rate at base line was at least $80 \%$ & $\mathrm{CH}$ & V/P \\
\hline $\begin{array}{l}\text { 4. Positive if the response after } 1 \text { year of follow-up was at least } 80 \% \text { of the number of participants at base line or if the } \\
\text { nonresponse was not selective (data shown) }\end{array}$ & $\mathrm{CH}$ & V/P \\
\hline $\begin{array}{l}\text { 5. Positive if the cases and referents were drawn from the same population and a clear definition of cases and referents } \\
\text { was given. Subjects with low-back pain during the previous } 90 \text { days must have been excluded from the reference group }\end{array}$ & $\mathrm{CR}$ & $\mathrm{V} / \mathrm{P}$ \\
\hline $\begin{array}{l}\text { 6. Positive if the participation rate of the cases and referents selected and invited to participate at base line was at } \\
\text { least } 80 \%\end{array}$ & CR & V/P \\
\hline \multicolumn{3}{|l|}{ Exposure measurements, physical load at work } \\
\hline $\begin{array}{l}\text { 7. Positive if data on physical load at work were collected and included in the statistical analysis, data on physical load } \\
\text { at work based on information about job title (job-exposure matrix) were not considered to be appropriate }\end{array}$ & $\mathrm{CH} / \mathrm{CR}$ & $V / P$ \\
\hline 8. Positive if data were collected by means of standardized methods of acceptable qualityc & $\mathrm{CH} / \mathrm{CR}$ & V/P \\
\hline \multicolumn{3}{|l|}{ Exposure measurements, psychosocial factors at work } \\
\hline $\begin{array}{l}\text { 9. Positive if data on psychosocial factors at work were collected and included in the statistical analysis. } \\
\text { 10. Positive if data were collected by means of standardized methods of acceptable qualityc }\end{array}$ & $\begin{array}{l}\mathrm{CH} / \mathrm{CR} \\
\mathrm{CH} / \mathrm{CR}\end{array}$ & $\begin{array}{l}\text { V/P } \\
\text { V/P }\end{array}$ \\
\hline \multicolumn{3}{|l|}{ Exposure measurements, other } \\
\hline $\begin{array}{l}\text { 11. Positive if data on physical or psychosocial exposure during leisure time were collected and included in the } \\
\text { statistical analysis }\end{array}$ & $\mathrm{CH} / \mathrm{CR}$ & V/P \\
\hline 12. Positive if data on historical exposure at work were collected and included in the statistical analysis & $\mathrm{CH} / \mathrm{CR}$ & V/P \\
\hline $\begin{array}{l}\text { 13. Positive if data on history of back pain, age and gender were collected and included in the statistical analysis. Data on } \\
\text { history of back pain should have been based on information about the presence of back pain during at least } 1 \text { year } \\
\text { before base line }\end{array}$ & $\mathrm{CH} / \mathrm{CR}$ & V/P \\
\hline 14. Positive if the exposure was measured in an identical manner among the cases and referents & $\mathrm{CR}$ & V/P \\
\hline 15. Positive if the exposure assessments were blinded with respect to disease status & CR & V/P \\
\hline 16. Positive if the exposure was assessed prior to the occurrence of the outcome & $\mathrm{CR}$ & V/P \\
\hline \multicolumn{3}{|l|}{ Assessment of back pain } \\
\hline $\begin{array}{l}\text { 17. Positive if based on standardized methods of acceptable quality, namely, positive if one of the following criteria were } \\
\text { met: (i) self-reported: data presented or in reference showed that the intraclass correlation coefficient was }>0.60 \text { or } \\
\text { the kappa was }>0.40 \text { for the test-retest reliability; (ii) registered data: data presented or in reference demonstrate that } \\
\text { the registration system is valid and reliable; (iii) physical examination blinded with respect to exposure status: data } \\
\text { presented or in reference showed that the intraclass correlation coefficient was }>0.60 \text { or the kappa was }>0.40 \text { for the } \\
\text { intraobserver reliability if only } 1 \text { observer is involved or the interobserver reliability if }>1 \text { observer is involved. If no } \\
\text { intraclass correlation coefficient or kappa had been computed, but the data presented showed clearly that the reliability } \\
\text { of the method was good, this criterion was also rated positively }\end{array}$ & $\mathrm{CH} / \mathrm{CR}$ & V/P \\
\hline 18. Positive if the time-period on which the assessment of back pain was based was at least one year & $\mathrm{CH}$ & V/P \\
\hline 19. Positive if data were collected at least once every three months or obtained from a continuous registration system & $\mathrm{CH}$ & $\mathrm{V} / \mathrm{P}$ \\
\hline 20. Positive if incident cases were included (prospective enrollment) & $\mathrm{CR}$ & V/P \\
\hline \multicolumn{3}{|l|}{ Analysis and data presentation } \\
\hline $\begin{array}{l}\text { 21. Positive if the method used for the statistical analysis was appropriate for the outcome studied and the measures of } \\
\text { association estimated according to this model (including confidence intervals) were presented }\end{array}$ & $\mathrm{CH} / \mathrm{CR}$ & V/P \\
\hline 22. Positive if the analysis included a stratified or multivariable analysis & $\mathrm{CH} / \mathrm{CR}$ & V/P \\
\hline $\begin{array}{l}\text { 23. Positive if the number of cases in the final multivariable model was at least } 10 \text { times the number of the independent } \\
\text { variables in the analysis }\end{array}$ & $\mathrm{CH} / \mathrm{CR}$ & $\mathrm{V} / \mathrm{P}$ \\
\hline
\end{tabular}

a This column shows whether a criterion pertains to the criteria list for cohort (CH) and/or case-referent (CR) studies.

b $I=$ criterion on informativeness, $V / P=$ criterion on validity/precision.

c This criterion was rated positively if one of the following criterla was met: direct measurement method: data presented or in reference showed that the intraclass correlation coefficient was $>0.60$ or the kappa was $>0.40$; observational method: data presented or in reference showed that the intraclass correlation coefficient was $>0.60$ or the kappa was $>0.40$ for the intraobserver reliability if only 1 observer was involved or the interobserver reliability if more than 1 observer was involved; self-reported: data presented or in reference showed that the intraclass correlation coefficient was $>0.60$ or the kappa was $>0.40$ for the test-retest reliability. If no intraclass correlation coefficient or kappa had been computed, but the data presented showed clearly that the reliability of the method was good, this criterion was also rated positively. 